Participation in ALA Legislative Day is critical for enhancing the visibility of academic libraries in the political process, for educating our Congressmen about the changing academic library and the issues affecting it, and for developing working relationships with Congressmen and key staff members. It is both intrinsically rewarding as an experience and very much essential for creating the type of information environment in which our institutions, our users and the larger community will thrive.

Please mark April 19, 1988, on your calendar. If you cannot come, please write or call your Congressmen to support this crucial effort by the library community.

\title{
ALA and its divisions
}

\author{
By Patricia Glass Schuman
}

ALA Treasurer

\section{Remarks of the ALA Treasurer to incoming divisional presidents-elect at the Divisional Leadership Program,} September 19, 1987.

$\mathbf{I}_{\mathrm{n}}$ In 1976 ALA adopted the principle that costs for divisional staff, programs, and publications should be funded from income derived from division dues and other activities. However, the general association budget would assume responsibility for certain basic services at no charge to divisions.

In 1982 an operating agreement between ALA and the divisions was adopted by ALA Council. A revision of this agreement has been drafted by the ALA staff. Divisional presidents will no doubt be asked to comment - and probably act on itduring their terms of office.

The purpose of the operating agreement is to define fiscal and administrative policies. Essentially it spells out the terms of the symbiotic relationship between ALA and its divisions. Those policies contained in the operating agreement have and will continue to have an impact on ALA's allocation of resources. This impact is not always obvious from the way the figures are presented in budgets and other ALA financial documents.

The interrelationship between ALA and its divisions must be viewed in the context of ALA's complex structure. This includes not only divisions but other membership units and departments that also sponsor the programs of the association and generate revenue. Publishing, Communications, and the eleven divisions of ALA are the three principal revenue-generating units. These, along with ALA offices, are our association's major service providers. Fiscal Services and Administrative Services provide essential support to these units.

The divisions provide programs at conferences, publications, standards and guidelines, regional workshops and continuing education courses, advisory services for members and non-members, and numerous important opportunities for members to serve on committees, to network, and to participate in the work of the association. Given the importance, size, and large membership base of the 
divisions, their role and contributions are an integral part of the development of ALA's long- and short-range financial and programmatic strategies.

In financial terms, the combined divisions represent almost $25 \%$ of all ALA revenues. Our other large revenue-producing units-Graphics, Conference, Communications and Publishing-bring in about $50 \%$ of all ALA revenues. They pay ALA overhead for indirect costs, and they return most of their department net revenues to ALA general funds.

Divisions do not pay overhead for indirect costs, nor do they return their net revenues to the general funds. Divisions do pay for printing and duplicating, postage, and overhead on certain revenuegenerating projects. ALA and the divisions share the costs of some activities, such as promoting awards and sponsoring the division leadership program.

The kinds of basic support that ALA provides for the divisions is spelled out in the operating agreement. These costs are considered general ALA overhead. We call them "indirect costs" because for the most part they represent shared services. While the amounts these services cost are only accounted for explicitly in what is called ALA's "indirect cost study," they are very real expenses paid for by the ALA general fund, and they have a very real impact on ALA's overall finances. As Everett Dirksen once pointed out to Congress, "A billion here-a billion there-pretty soon you're talking real money."

Basic Services provided to divisions at no charge include:

- administrative services like switchboard services, telephone equipment, purchasing, shipping, receiving, warehousing;

- conference arrangements like staff travel and housing, postage, photocopying, etc.;

- fiscal services;
- library services;

- membership records and processing;

- office space and related costs like heat, maintenance, etc.;

- office supplies;

- furniture and equipment, such as desks, chairs, file cabinets, etc.;

- subscription services, including invoicing, maintaining records, etc.;

- personnel services;

- mail service and postage, except where postage is more than 6 times the prevailing first-class rate.

While the current operating agreement used a 1981 figure of $\$ 476,000$ for the cost of providing these services, the 1986 estimated cost to ALA's general fund for providing services to divisions was $\$ 1,173,000$. This figure is from a recently completed indirect cost study of all ALA units. This study is done every few years to determine what overhead rate to charge for various outside grants and other projects. And, while units can-and no doubt will - argue with some of the estimates made of their unit, these are very real costs, no matter whom they are charged to.

There's one common factor in the allocation of overhead, general and administrative, or indirect costs in any organization: no one ever thinks they are fair, and everyone thinks they are too high. But realistically, if each unit tried to set up its own separate service, costs for each unit would be astronomically higher.

Also implicit, though not explicit, in the operating agreement is that the ALA cash flow covers division cash flow. If a division, for example, bills a customer for a publication, the division is credited for the cash immediately, though the customer may take several months to pay ALA. On the other hand, money the divisions earn also helps the total ALA cash flow. Most of the expenses for basic services to divisions are charged to the general fund.

\section{TABLE 1}

\section{Basic Support Services Provided to Divisions FY 1986}

Communications

Administrative Services (net)

$\$ 133,000$

Library services

Executive Office, Handbook, Council

Fiscal Services

Legal, audit, insurance fees

Membership Records \& Processing

Office space

Warehouse space

Office supplies (net)

Personnel Services

Order Billing \& CPU (net) 
Table 1 shows the cost of basic support services for divisions paid from ALA's general and plant funds: $\$ 1,173,000$. Because the ALA general fund pays these overhead expenses for divisions, you will see when you look at any of ALA's budget or financial documents that general fund expenses look high-and divisions look low-in comparison to revenues. Basically, at ALA we do not charge overhead to offices, committees, or divisions. Divisions are charged overhead only on special projects or conferences. Roundtables are charged minimal overhead. We do charge overhead to grants, conference, graphics, publishing, and other special activities. That's the way we have chosen-for policy reasons-to divide up ALA's fiscal and programmatic responsibilities.

Table 2 shows you the revenues and expenses by fund under our current system of cost allocation, and how each fund would look if they were charged the full cost of overhead. As you can see, there is a dramatic difference. The general fund would have a substantial surplus-divisions a substantial loss. The difference is the result of our policy and program decisions. These decisions govern how ALA decides to slice up its pie.

There is only one pie. ALA is one organization, one legal and financial entity. All ALA funds fold into one bottom line. ALA financial statements have to be viewed in the context of policy. It is these policy decisions that affect how each fund looks.

This brings us to the questions of "fund" and "fund balance." ALA has chosen to account for its revenues by fund. We have over 250 funds and some 10,000 separate accounts. The results of all of the activity - planned for the future as in a budget document, or compiled for year-end resultscombine to make up a fund balance. Table 3 shows how each fund feeds into one overall ALA fund balance. The fund balance, when used in terms of ALA's year-end financials, is not "cash in the bank." What it represents is ALA's equity, or net worth.

If we were a corporation, the fund balance might be called "retained earnings" or "shareholders" or "owners' equity." I like to think of ALA's fund balance as "members' equity." We calculate this fund balance-or members' equity-by subtracting ALA's liabilities (what it owes) from its assets (what it owns).

As you can see from Table 4, divisions overall are showing a strong improvement and a large positive overall fund balance. But much of this is ACRL and Choice. Again, this balance is not a cash balance. It is rather a cumulative balance reflecting net worth.

PLA and YASD have turned around their deficits, and AASL will turn around this year because of their successful conference last fall. RTSD has implemented numerous cost-saving measures. The ALA Executive Board has set up a special committee to clarify the problem of ASCLA. ALTA has taken steps to turn around its deficit in 1987.

Table 5 shows you that had divisions been charged for basic services instead of absorbing the costs in the general fund, divisional fund balances would be negative and the general fund would be positive. In fact, had divisions been paying for these services since 1982 every division would have a substantial negative fund balance ranging from $\$ 200,000$ to $\$ 900,000$. It is estimated that the total negative divisional fund balance would be over $\$ 6$ million-because that money would have been paid to the general fund from division revenues.

Despite the "fund balance" listed for each individual fund, the overall number is the one that counts. $93 \%$ of ALA's fund balance is held by the endowment fund-our investments.

One could come to the conclusion, and some people have, looking at ALA finances, that division funds are supporting ALA. Quite the contrary. Remember, individual ALA fund balance figures look the way they do because they reflect the policy decisions we have made about how ALA will pay for certain things - and who will pay for them. While the general fund is in a deficit, it has advanced over $\$ 1.5$ million to the plant fund for improvements,

TABLE 2

1986 Revenues and Expenses by Fund with All Overhead Costs

\begin{tabular}{|c|c|c|c|c|}
\hline & Revenues & $\begin{array}{c}\text { Direct and } \\
\text { Overhead } \\
\text { Expenses }\end{array}$ & $\begin{array}{c}\text { Estimated } \\
\text { Gain (Loss) } \\
\text { with } \\
\text { Overhead } \\
\text { Expenses } \\
\end{array}$ & $\begin{array}{c}1986 \\
\text { Actual } \\
\text { Gain } \\
\text { (Loss) } \\
\end{array}$ \\
\hline General Fund & $\$ 11,001,000$ & $\$ 9,785,000$ & $\$ 1,216,000$ & $\$ 330,000$ \\
\hline Division Fund & $\$ 4,264,000$ & $\$ 5,042,000$ & $(\$ 778,000)$ & $\$ 395,000$ \\
\hline \multicolumn{5}{|l|}{ Round Tables, Grants } \\
\hline \& Special Activities & $\$ 1,318,000$ & $\$ 1,317,000$ & $\$ 1,000$ & $\$ 46,000$ \\
\hline \multicolumn{5}{|l|}{ Plant Fund-_ } \\
\hline Tenant Space & $\$ 476,000$ & $\$ 543,000$ & $(\$ 67,000)$ & $(\$ 399,000)$ \\
\hline TOTAL ALA & $\$ 17,059,000$ & $\$ 16,687,000$ & $\$ 372,000$ & $(\$ 372,000)$ \\
\hline
\end{tabular}


TABLE 3

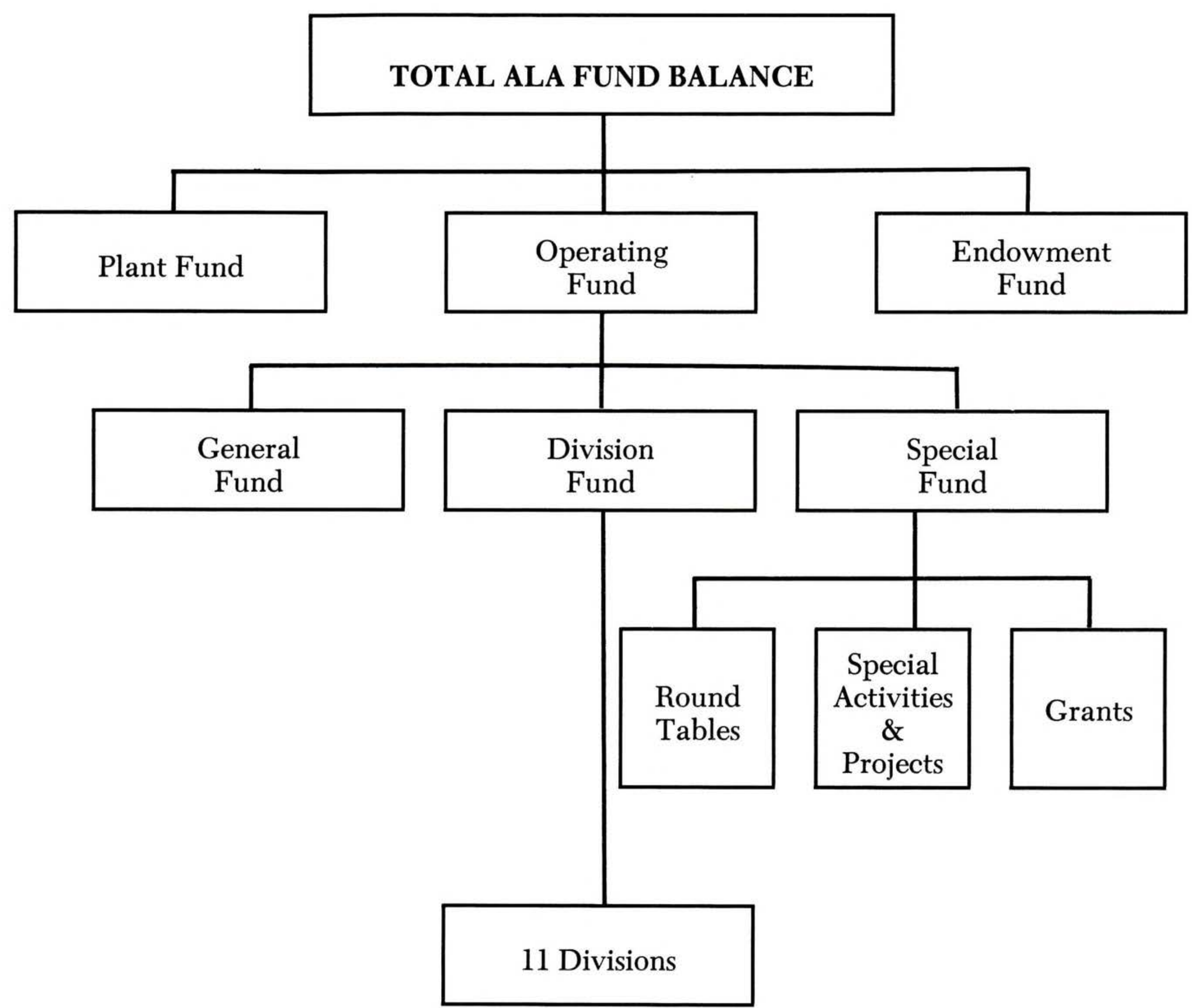

equipment, and operations. Since we do not charge any of our units rent, or for the cost of financing equipment loans, there is little hope of the plant fund paying back the general fund. In fact the plant fund will probably be negative in 1987. In addition, the ALA general fund pays overhead costs estimated at approximately $\$ 3,416,000$.

It should be no surprise to any of us that over $30 \%$ of ALA's indirect costs are divisional. After all, divisions provide a large portion of the ALA program. About two-thirds of our members belong to at least one division; $27 \%$ belong to two or more.

TABLE 4

\section{Division Fund Balances}

\begin{tabular}{lcc}
\hline \hline & 1986 & 1985 \\
\hline AASL & $\$(60,000)$ & $\$(63,000)$ \\
ACRL \& Choice & 782,000 & 497,000 \\
ALSC & 46,000 & 33,000 \\
ALTA & $(6,000)$ & $(3,000)$ \\
ASCLA & $(10,000)$ & $(32,000)$ \\
LAMA & 45,000 & 41,000 \\
LITA & 34,000 & 24,000 \\
PLA & 44,000 & $(6,000)$ \\
RASD & 45,000 & 45,000 \\
RTSD & $(59,000)$ & $(63,000)$ \\
YASD & 4,000 & $(17,000)$ \\
\multicolumn{1}{c}{ TOTAL } & $\$ 865,000$ & $\$ 456,000$ \\
\hline
\end{tabular}




\section{TABLE 5}

Fund Balances August 31, 1986

\begin{tabular}{lcc}
\hline \hline & $\begin{array}{c}\text { Estimated } \\
\text { Fund Balance } \\
\text { with Overhead } \\
\text { Expenses }\end{array}$ & $\begin{array}{c}\text { Actual } \\
\text { Fund } \\
\text { Balance }\end{array}$ \\
\hline General & $(\$ 50,000)$ & $(\$ 781,000)$ \\
Division & $(\$ 322,000)$ & $\$ 865,000$ \\
Special & $\$ 203,000$ & $\$ 247,000$ \\
Operating Fund Balance & $(\$ 169,000)$ & $\$ 331,000$ \\
Plant Fund & $\$ 502,000$ & $\$ 2,000$ \\
Endowment Fund & $\underline{\$ 4,140,000}$ & $\$ 4,140,000$ \\
\multicolumn{1}{c}{ TOTAL ALA FUND BALANCE } & $\underline{\$ 4,473,000}$ & $\underline{\underline{\$ 4,473,000}}$ \\
\hline
\end{tabular}

The $36 \%$ of our members that don't belong to divisions do support divisions. A portion of their dues pays for division basic services from the ALA general fund. For every dollar a division spends, the general fund pays 30 cents.

All members benefit from division programs. $78 \%(1,789)$ of all meetings held at ALA annual conference were divisional. $82 \%(1,070)$ of all ALA committees are divisional.

Since our dues structure change and the operating agreement, ALA's general fund revenues have increased $104 \%$; division revenues have grown by $180 \%$. ALA's overall expenses have grown $101 \%$; division expenses have risen by $184 \%$. ALA's overhead costs have increased $76 \%$.

ALA's explosive growth rate has begun to slow down. We are moving towards more analytical program and financial planning. This is essential. Our resources are finite, and we can't afford to let over 10,000 separate accounts turn into 20,000 . Divisions have been creative and successful in bringing additional program and revenue to ALA. In fact, divisions earn over $25 \%$ of all ALA revenues. Since the new dues structure, 4 divisions have held 11 national divisional conferences. Several others have launched additional journals or newsletters for their members. Divisions have increased their dues by an average of $67 \%$, while ALA general membership dues grew by $30 \%$.

But even with the free provision of many basic services to them from the general fund, some of our divisions are finding it difficult to make it financially. These difficulties may be compounded as ALA moves towards more conservative methods of accounting and budgeting during the next fiscal year.

Few of us have ever heard of Fra Luca Perioli, the inventor of double-entry bookkeeping. But he has probably had much more influence on human life then either Dante or Michelangelo.

It is essential that division programs do not suffer because of accounting methodologies. It is, after all, program that is important to us as members, not money and growth per se. It will take all of our efforts and creativity-individually and collectively - to ensure that each of our ALA units fulfills its goals. This collaborative effort means fitting the pieces together, recognizing that we are part of a whole.

No one person can whistle a symphony. It takes a full orchestra to play it.

\section{Missed Annual Conference?}

Audiocassette tapes of selected programs at the San Francisco Conference are still available from ACTS, Inc., 1025 E. Clayton Road, Ballwin, MO 63011; (314) 394-0611.

The ACRL programs on cassette are: "Information for, by, and about Women of Color in the United States" (LA8707, \$11.95); "Acquisitions by Exchange: The Administrator's Viewpoint" (LA8729ab, \$23.90); "Learning to Teach: Promoting Quality in Bibliographic Instruction" (LA8734ab, \$23.90); “Teacher Education Reform:
A Partnership" (LA8741 ab, \$23.90); "Asia and Africa in Undergraduate Library Collections" (LA8743ab, \$23.90); and "Artificial Intelligence: Convergence of Mind and Machine?" (LA8760ab, $\$ 23.90$ ).

Shipping and handling charges are $\$ 1.00$ for the first cassette and $\$ .50$ (Canada $\$ 1.00$ ) for each additional cassette. Overseas air mail charges are $\$ 3.00$ for the first cassette and $\$ 1.00$ for each additional. If the order is to be billed, there is a $\$ 5.00$ billing charge. 